\title{
Status of the Global Cotton Germplasm Resources
}

\author{
B. T. Campbell,^ S. Saha,^ R. Percy, J. Frelichowski, J. N. Jenkins, W. Park, C. D. Mayee, V. Gotmare, \\ D. Dessauw, M. Giband, X. Du, Y. Jia, G. Constable, S. Dillon, I. Y. Abdurakhmonov, A. Abdukarimov, \\ S. M. Rizaeva, A. Adullaev, P. A. V. Barroso, J. G. Pádua, L. V. Hoffmann, and L. Podolnaya
}

\begin{abstract}
The cultivated Gossypium spp. (cotton) represents the single most important, natural fiber crop in the world. In addition to its fiber, the oil and protein portion of the cottonseed also represents significant economic value. To protect the worldwide economic value of cotton fiber and cotton byproducts, coordinated efforts to collect and maintain cotton genetic resources have increased over the last $100 \mathrm{yr}$. The classified genetic resources of cotton are extensive and include five tetraploid species in the primary gene pool, 20 diploid species in the secondary gene pool, and 25 diploid species in the tertiary gene pool. This report provides information on the status and contents of eight major cotton germplasm collections present across the world. Based on the findings of this report, a number of classified Gossypium species are not maintained in these collections, and several are underrepresented and vulnerable to extinction. This report presents several critical challenges and opportunities facing international efforts to enhance and preserve the world's Gossypium genetic resources. Multinational communication and collaboration are essential to protect, secure, and evaluate the global cotton germplasm resources. Without global, collaborative efforts, the rarest and most unique cotton germplasm resources are vulnerable to extinction.
\end{abstract}

B.T. Campbell and W. Park, USDA-ARS Coastal Plains Soil, Water, and Plant Research Center, 2611 W. Lucas St., Florence, SC 29501; S. Saha and J.N. Jenkins, USDA-ARS Crop Science Research Lab., 810 Hwy. 12 E., Mississippi State, MS 39762; R. Percy and J. Frelichowski, USDA-ARS, Crop Germplasm Research Unit, 2881 F\&B Rd., College Station, TX 77845; C.D. Mayee and V. Gotmare, Central Institute for Cotton Research, Post Bag No. 2, Shankar Nagar PO, Nagpur-440010, Maharashtra, India; D. Dessauw and M. Giband, CIRAD, Ave. Agropolis, 34398 Montpellier Cedex 5, France; X. $\mathrm{Du}$ and Y. Jia, Cotton Research Institute of CAAS, Anyang, Henan 455000, China; G. Constable, CSIRO Plant Industry, Locked Bag 59, Narrabri NSW 2390, Australia; S. Dillon, Australian Tropical Grains Germplasm Centre, P.O. Box 201, Biloela QM 4715, Australia; I.Y. Abdurakhmonov, A. Abdukarimov, S.M. Rizaeva, and A. Adullaev, Center of Genomic Technologies, Institute of Genetics and Plant Experimental Biology, Academy of Sciences of Uzbekistan, Yuqori Yuz, Qibray Region, 111226 Tashkent, Uzbekistan; P.A.V. Barroso and L.V. Hoffmann, Embrapa Cotton, Brazilian Agriculture Research Corporation, Osvaldo Cruz, 1143, Centenário, Campina Grande, PB, Brazil; J.G. Pádua, Embrapa Cenargen, Caixa Postal 02372, Brasilia, Brazil 70770-917; L. Podolnaya, VIR, 42-44 B. Morskaya St., 190000, St. Petersburg, Russia. Mention of a trade name, proprietary product, or specific equipment does not constitute a guarantee or warranty by the USDA and does not imply approval of a product to the exclusion of others that may be suitable. B.T. Campbell and S. Saha contributed equally to this work. Received 28 Sept. 2009. ^Corresponding authors (todd.campbell@ars.usda.gov, sukumar.saha@ars.usda.gov).

$\mathrm{P}$ LANT Genetic Resources and germplasm collections represent a vital portion of the world's natural resources. Genetic resources and germplasm collections are reservoirs of genes and genotypes necessary to protect humankind of present and future

Published in Crop Sci. 50:1161-1179 (2010).

doi: 10.2135/cropsci2009.09.0551

Published online 21 May 2010.

(C) Crop Science Society of America | 5585 Guilford Rd., Madison, WI 53711 USA

All rights reserved. No part of this periodical may be reproduced or transmitted in any form or by any means, electronic or mechanical, including photocopying, recording, or any information storage and retrieval system, without permission in writing from the publisher. Permission for printing and for reprinting the material contained herein has been obtained by the publisher. 
Abbreviations: ATGGC, Australian Tropical Grains Germplasm Centre; AusPGRIS, Australian Plant Genetic Resources Information System; CGIAR, Consultative Group on International Agricultural Research; CICR, Central Institute for Cotton Research; CIRAD, Centre de Coopération Internationale en Recherche Agronomique pour le Développement; CSIRO, Commonwealth Scientific and Industrial Research Organisation; FAO, Food and Agriculture Organization of the United Nations; GRIN, Germplasm Resources Information Network; ICGI, International Cotton Genome Initiative; IPGRI, International Plant Genetic Resources Institute; NBPGR, National Bureau for Plant Genetic Resources; NCGRP, National Center for Genetic Resources and Preservation; USSR, Union of Soviet Socialist Republics; VIR, N.I. Vavilov Institute of Plant Industry.

generations from emerging crop diseases and vulnerabilities. Preservation of the cultivars, landraces, and wild relatives of important plant species provides a basic foundation to promote and sustain agriculture. It protects mankind from future, and many times unforeseen, crop vulnerabilities, thus protecting future food, feed, and fiber supplies. Preserved genetic resources will supply plant breeders, farmers, and other agricultural scientists with the genetic materials to develop new crop cultivars and hybrids that secure future food, feed, and fiber supplies.

The value of germplasm, already collected and conserved, is greatly appreciated with reference to agro-biodiversity and searching for new sources of useful genes. In the recent history of the world, governments, individual organizations, and institutions have realized the importance of genetic resources and organized efforts for storage, maintenance, propagation, and collection through explorations of many plant species and their wild relatives in gene banks or germplasm collection centers around the world. The importance of genetic resources was recognized at the intergovernmental platform under the Food and Agriculture Organization of the United Nations (FAO) as the "common heritage of mankind" which should be made available without restriction (FAO, 2009). The value of germplasm collections is now well recognized with the International Treaty on Plant Genetic Resources for Food and Agriculture implemented on 29 June 2004. The objectives of this Treaty are "the conservation and sustainable use of plant genetic resources for food and agriculture and the fair and equitable sharing of the benefits arising out of their use, in harmony with the Convention on Biological Diversity, for sustainable agriculture and food security."

Intensive plant breeding programs of many crop plants have capitalized on genetic resources and germplasm collections to develop improved genotypes with significant gains in yield. These intensive hybridization and selection plant breeding programs have also unintentionally narrowed the genetic base and increased genetic vulnerability of many of the world's most important crops. A few examples of serious crop vulnerabilities resulting from the combination of disease outbreak and increased genetic uniformity include threats to potato (Solanum tuberosum L.), grapevine (Vitis L.), banana (Musa acuminata Colla), and maize (Zea mays L.). The Irish potato famine of the 1840s resulted because the potato crop was completely devastated from leaf blight disease [Phytophthora infestans (Mont.) de Bary] due to the uniformity of susceptible potato varieties grown (Ramanatha Rao and Hodgkin, 2002). Panama disease, commonly known as Fusarium wilt of banana [Fusarium oxysporum Schltdl.:Fr. f. sp. cubense (E. F. Sm.) W. C. Snyder $\&$ H. N. Hansen], nearly devastated the banana industry worldwide in the 1950s due to the uniform production of susceptible cultivars (Ploetz and Pegg, 1997). Pierce's disease of grapevine, caused by the pathogen Xylella fastidiosa Wells et al., represents an emerging disease that threatens worldwide grape production because nearly all European, American, and French-American hybrid grape genotypes are extremely susceptible (Hopkins and Purcell, 2002). In the United States, the genetic uniformity of corn hybrids resulted in major susceptibility to southern corn leaf blight disease [Bipolaris maydis (Nisikado \& Miyake) Shoemaker] that decreased corn production in the southern United States by $25 \%$ (Tatum, 1971). Fortunately, germplasm collections provided scientists the necessary genetic resources to identify and transfer resistance against such catastrophic outbreaks into improved cultivars and hybrids.

Although plant explorations date to many centuries ago, recorded history of extensive collecting and maintaining plant genetic resources can be traced to several early plant explorers. Several prominent, but not all inclusive, early plant explorers include Carl Linnaeus, Charles Darwin, and Joseph Banks. The British in particular, under the leadership of Sir Joseph Banks, performed many collecting expeditions across the world and began preserving them at the Royal Botanic Gardens at Kew near London in the 18th century (Damania, 2008). More recently, Frank Meyer and Nikolai Vavilov represent two well-known plant explorers with major impact in the field of genetic resource conservation. Descriptions of Meyer and Vavilov, in addition to a comprehensive review of plant genetic resources, are summarized by Damania (2008). Briefly, in the early 1900s, the U.S. Office of Foreign Seed and Plant Introductions sent Frank Meyer to East Asia to collect plant genetic resources with relevance to the United States. Nikolai Vavilov also began collecting plant genetic resources in the early 20th century and coordinated efforts to store and maintain these collections at the All-Union Institute of Plant Industry at St. Petersburg, Russia. The first U.S. repository of crop seeds was established at Ames, IA, in 1947, and the first, long-term national storage facility was established at Fort Collins, CO, in 1958. By the 1970s, the Consultative Group on International Agricultural Research (CGIAR) formed International Agricultural Research Centers in 
developing countries and began efforts to collect and conserve plant genetic resources for the world's most important food and feed crops. Hence, over the course of the 21st century, organized efforts were placed into action with the task of collecting, maintaining, and distributing the genetic resources of many plant species.

The cultivated Gossypium spp. (cotton) represents the single most important, natural fiber crop in the world. On a worldwide basis, the value of cotton during 2005 to 2007 ranged from US\$27-29 billion (National Cotton Council, Memphis, TN). This average worldwide value of cotton was equivalent to $\sim 20 \%$ of the total 2007 gross domestic product of the Philippines (US $\$ 144$ billion; World Bank). In addition to its fiber, the oil and protein portion of the cottonseed also represents significant economic value and oil and protein are used in a variety of ways, including animal feed and industrial lubricants. To protect the worldwide economic value of cotton and cotton byproducts, coordinated efforts to collect and maintain cotton genetic resources have increased over the last $100 \mathrm{yr}$. The earliest known collection of cotton was established by J. P. B. von Rohr in the late 18th century under a commission from the Danish King. He maintained a garden of cottons from the Caribbean and South America at St. Croix in the Danish West Indies (now the Virgin Islands) (von Rohr, 1791-1793). In the mid-19th century, the Italian botanists Parlatore and Todaro assembled a collection of cotton (Todaro, 1877). The first major contributor to genetic resource accumulation and disbursement was the former Empire Cotton Growing Company, chartered by Britain to grow cotton in areas settled outside the United States (Hutchinson et al., 1947). Although the collection and introduction of cotton into the United States has a long and interesting history, the origins of the organized, modern U.S. germplasm collection can be traced to collection efforts made in the early 20th century in response to a crisis similar to that which occurred in the potato, corn, and banana industries. The USDA, in response to the devastation to the U.S. cotton industry caused by the boll weevil (Anthomonus grandis Boheman), conducted several collecting trips to Central America and northern South America in attempts to find resistant germplasm (Percival et al., 1999). As a result, efforts were made to develop earlier maturing cultivars to avoid the devastating effects of the boll weevil (Smith et al., 1999). During this same time interval, the USDA also made organized efforts to introduce extra long staple G. barbadense L. cottons to create a cotton industry in the arid Southwest. Cotton has been a crucial export for the United States, but other nations have a long history of production and have seen the necessity of collecting germplasm and maintaining it to protect the genetic stability of their industries. Today at least eight nations already have major collections of cultivated and wild-collected cotton and Gossypium germplasm.

The genetic resources of cotton are extensive, dispersed globally across five continents, and consist of approximately
45 diploid (A-G and $\mathrm{K}$ genomes, $2 n=2 x=26)$ and five tetraploid species (AD genome, $2 n=4 x=52$ ) that belong to the Malvaceae (Brubaker et al., 1999; Fryxell, 1992). These species have been classified into primary, secondary, and tertiary germplasm pools (Stewart, 1994) on the basis of the relative genetic accessibility and utility of species to crop improvement efforts (Harlan and de Wet, 1971). Currently there are five species assigned to the primary germplasm pool, 20 species assigned to the secondary germplasm pool, and 25 species assigned to the tertiary germplasm pool. The five allotetraploid species (AD genome) of the primary Gossypium germplasm pool had a monophyletic origin about 1 to 2 million years ago from a polyploidy event resulting from an unusual hybridization between an invasive A-genome diploid species of Old World and a D-genome New World indigenous diploid species (Wendel and Cronn, 2002; Paterson et al., 2004). Two of the allotetraploid species, G. hirsutum L. (the source of Upland cotton) and G. barbadense L. (the source of Pima, Sea Island, or Egyptian cotton), were independently domesticated about 4000 yr ago (Wendel et al., 1995; Dillehay et al., 2007). The other three AD tetraploid cotton species have not been domesticated and are distributed widely: G. mustelinum Miers ex Watt, primarily in northeast Brazil (Wendel et al., 1994; Barroso et al., 2009); G. darwinii Watt endemic to the Galapagos Islands (Wendel and Percy, 1990); and G. tomentosum Nuttall ex Seemann endemic to the Hawaiian Islands (Dejoode and Wendel, 1992; Hawkins et al., 2005). These species are considered as true wild species (Westengen et al., 2005). Today the two cultivated tetraploid species, G. hirsutum and G. barbadense, account for the majority of world production. The most widely grown species worldwide ( $>90 \%$ of the total area) is G. hirsutum because of its high yield potential and broad adaptation.

The center of origin for G. hirsutum is considered to be in Mexico, but diverse forms are spread throughout Central America and the Caribbean. According to archaeobotanical findings, G. hirsutum probably was domesticated originally within the southern end of the Mesoamerican gene pool (Wendel et al., 1995; Brubaker et al., 1999). It has been suggested that southern Mexico-Guatemala and the Caribbean are the two primary centers of genetic diversity within $G$. hirsutum (Brubaker et al., 1999), with the Mexico-Guatemala gene pool considered as the site of original domestication and primary center of diversity. Within this range, G. hirsutum exhibits diverse types of morphological forms, including wild, primitive to domesticated accessions. Hutchinson et al. (1947) classified the diverse morphological forms of G. hirsutum into seven geographical races, including (i) latifolium, (ii) punctatum, (iii) marie-galante, (iv) morrilli, (v) palmeri, (vi) yucatanense, and (vii) richmondi.

Gossypium barbadense is distributed geographically in South America, southern Mesoamerica, and the Caribbean basin (Fryxell, 1976). Investigations of the species' diversity 
indicates that its center of diversity, and apparent center of origin, resides in Peru and Ecuador, from which it diffused to eastern South America, the Caribbean, and finally to Central America (Percy and Wendel, 1990). Gossypium barbadense provides about $9 \%$ of world cotton production, and was originally cultivated in the coastal islands and lowlands of the United States, where it became known as Sea Island cotton. Sea Island cottons and likely other forms of G. barbadense were then introduced into the Nile Valley of Egypt to produce long-staple fine fibers and known as Egyptian cotton (Abdalla et al., 2001) and further developed in regions of the southwestern United States to become 'Pima' Cotton.

Since domestication, evidence indicates that human selection has caused considerable changes in cotton, which include an annual plant habit, photoperiod insensitivity, early flowering, larger boll size, yield, and fiber qualities ranging from greater fiber strength, fineness, and length (Chaudhary et al., 2009). Some of these selection activities, such as selection for photoperiod insensitivity, may have caused genetic bottlenecks in cultivated cotton and all have been accompanied by losses in genetic diversity. The diversity of commercial cotton cultivars and advanced germplasm lines has been studied using numerous methods. Although pedigree-based methods such as coefficient of ancestry suggested low amounts of genetic uniformity (May et al., 1995; Van Esbroeck et al., 1998), modern DNA-based genetic diversity methods consistently suggest a high degree of genetic uniformity within cultivated $G$. hirsutum (Gutierrez et al., 2002). Because modern DNAbased genetic diversity methodology is considered more precise and provides greater coverage of the genome, the molecular findings of low genetic diversity have renewed concern about genetic uniformity and vulnerability in the cotton community (Van Becelaere et al., 2005). A recent report by Wallace et al. (2009) provides a discussion of anticipated genetic vulnerability associated with increased genetic uniformity. Two specific and current global threats highlighted by Wallace et al. (2009) include vulnerability to Fusarium wilt Race 4 [F. oxysporum Schlechtend.:Fr. f. sp. vasinfectum (Atk.) W.C. Snyder \& H.N. Hans.] and the cotton leaf curl virus. For example, all current U.S. cotton cultivars are susceptible to both global threats. The rate of change in cotton yield has also been declining steadily through out the world since the early 1980s. For example, in 1998 the average U.S. cotton yield reached an alarming rate of decline of about $16.8 \mathrm{~kg}^{-1} \mathrm{ha}^{-1} \mathrm{yr}^{-1}$ (3.3\% annual rate). In addition, the year-to-year variability in U.S. cotton yield was almost four times greater in the period from 1980 to 1998 than in 1960 to 1979 (Paterson et al., 2004). Currently, U.S. Upland cotton breeding programs primarily rely on crossing of a few elite lines of closely related genotypes with high yield and superior fiber qualities and reselection of the existing cultivars (Van Esbroeck and Bowman, 1998). The overexploitation of fewer cultivars on larger areas both by plant breeders and farmers is a primary contributor to the genetic erosion of the cotton germplasm base. As a consequence, the narrow genetic diversity available into the primary gene pool caused stagnant yield, declining fiber quality, and increasing genetic vulnerability to biotic and abiotic stresses (Gingle et al., 2006).

Countering the genetic paucity in commercial cotton is a remarkable morphological and physiological diversity existing among the noncultivated Gossypium species of all germplasm pools. Reacting to diverse ecological and environmental conditions of the tropical and subtropical regions in the world, these species exhibit a broad range of adaptation, ranging from fire-adapted, herbaceous perennial diploid species in northwest Australia to small trees dropping their leaves to escape the dry season in southwest Mexico (Percival et al., 1999). Therefore, the wild cotton species of the secondary and tertiary germplasm pools represent a tremendous genetic repository for improving cotton productivity. Within the primary germplasm pool, the variability available from three wild species has been poorly characterized and barely tapped. Although plant introduction and germplasm collection have played a major role in the history of cotton improvement (McCarty and Percy, 2001), the potential for improvement using genetic resources within germplasm collections has not been fully realized.

Recently, the International Cotton Genome Initiative (ICGI; http://icgi.tamu.edu/ [verified 27 Mar. 2010]), an organization with $>500$ members from major cottongrowing countries, established a "Germplasm and Genetic Stocks Work Group" to address the major concerns associated with cotton genetic vulnerability and the crucial roles of germplasm and genetic stocks faced by the world cotton community (Brubaker et al., 2000). At the most recent international ICGI conference in Anyang, China, opportunities and challenges of cotton germplasm collections were presented and discussed (Percy, 2008). Following this discussion, we initiated a consolidated effort among the cotton germplasm collection centers of major cotton-growing countries to describe the status of the principal cotton germplasm collections in the world. Our goal is to provide the cotton community a useful document describing the status, methods, and policies of the worldwide cotton germplasm collections in germplasm collection centers of the major cotton-growing countries. This information will be an invaluable resource to document the status of cotton germplasm collections worldwide and highlight cotton germplasm concerns to ensure the future supply for sustainable cotton production.

\section{CURRENT WORLD COLLECTIONS}

The focus of this report will be on the dedicated germplasm collections present in Australia, Brazil, China, France, India, Russia, United States, and Uzbekistan. Although there are a few other cotton germplasm collections present in other 
countries of the world, these eight countries represent the majority of the world's cotton germplasm resources. Each country has a germplasm storage and conservation program in place. In the following sections, each of the eight germplasm collections will be described in more detail. We provide information in the following sections for each germplasm collection center regarding: (i) members of the collection, (ii) maintenance and storage procedures, (iii) seed request and disbursement, (iv) funding apparatus and staffing, (v) characterization methodology, (vi) data management, and (vii) past and present explorations. The contents and distribution of cotton germplasm accessions across the eight collections are summarized in Tables 1 and 2 . Table 1 provides a summary of the primary cultivated tetraploid species (G. hirsutum and G. barbadense), while Table 2 provides a summary of wild accessions existing in the primary, secondary, and tertiary gene pools across collections. Figure 1 shows a partial array of Gossypium flower diversity present in the global germplasm collections.

\section{Australia}

Cultivated cotton was first introduced to Australia in the late 18th century but was only a small opportunity crop until irrigation schemes in the 1960s led to a rapid increase in area and production. Cotton reached a peak of production in 1999 with 535,000 ha, producing >3 million bales at a yield of $2000 \mathrm{~kg} \mathrm{ha}^{-1}$. Sustained drought since then has reduced the area to 157,400 ha in 2008, with New South Wales producing $74 \%$ of the crop and Queensland 26\%. Almost all local textile manufacturing capacity has closed, so all raw cotton is exported. Drought and regulatory reactions to climate change in reducing irrigation allocations highlight the need for useful genetic diversity to address water use efficiency and drought-tolerance objectives.

Australia has a unique combination of heavy clay soil, and numerous pests and diseases, as well as climate factors which impact cotton production. A local breeding program has selected for adaptation to local conditions, with strong progress in yield due to breeding of $1.8 \% \mathrm{yr}^{-1}$ (Constable et al., 2001). Before 1980, Australian plant breeders acquired and maintained their own germplasm collections. However, the Commonwealth and State governments established a network of eight genetic resource centers to conserve national germplasm collections of field crops and forages in the early 1980s. Over the past $15 \mathrm{yr}$, these centers have worked independently with limited coordination between host organizations primarily responsible for operating the centers and maintaining the germplasm collections. The postentry plant quarantine services were made available free of charge by the Australian Quarantine and Inspection Service until 1995 when operation of postentry plant quarantine facilities was transferred to the states, and each genetic resource center was responsible for operating its own quarantine facility.
Currently, cotton collections in Australia reside in two places: (i) the Commonwealth Scientific and Industrial Research Organisation (CSIRO Plant Industry), Narrabri, NSW; and (ii) Australian Tropical Grains Germplasm Centre (ATGGC; http://www.dpi.qld.gov.au/auspgris, [verified 27 Mar. 2010]), Biloela, QLD. The CSIRO cotton collection is maintained by one full-time staff and seasonal temporary staff, while the ATGGC collection (of which cotton is one crop) is maintained by three full-time staff and seasonal temporary staff. The CSIRO collection is funded through dedicated programs provided by CSIRO. The ATGGC collection is currently only funded to maintain germplasm accessions under long-term storage. At present, no funding is available to regenerate accessions of the ATGGC collection.

\section{CSIRO Collection}

There have been germplasm explorations by CSIRO for native Australian diploid cottons (Craven et al., 1994), but this activity ceased $10 \mathrm{yr}$ ago. The collection has grown through time (the breeding program only began in 1972), with requests or exchange of seed with other breeders and collections to gather material with variability in growth habit, fiber quality, and disease resistance in particular. The collection currently consists of 542 G. hirsutum accessions, 63 G. barbadense accessions, and 30 race and wild diploid species. The collection is maintained at $7^{\circ} \mathrm{C}$ and $50 \%$ relative humidity. Two backup collections are also maintained and consist of $10 \mathrm{~g}$ of seed of each accession at an additional cool room at CSIRO and another research institute nearby. Each seed lot is renewed every $10 \mathrm{yr}$ or less. CSIRO has an internal database to record seed source and characterization data that is not publicly available. This database is also used to track incoming and outgoing seed. CSIRO policy is to support genuine exchange of material with breeders. The protocol is by direct contact and discussion; exchange of a Material Transfer Agreement is necessary.

There are numerous examples of germplasm utilization in Australia to face production vulnerabilities and develop new cultivars. Multiadversity resistance germplasm lines from the U.S. cotton collection were crossed to Australian accessions to develop bacterial blight [Xanthomonas campestris pv. malvacearum (Smith) Dye] resistance. Currently, all cultivars grown in Australia are resistant to bacterial blight. In addition, germplasm accessions from India and China have been crossed to Australian accessions to develop Fusarium wilt-resistant cultivars.

\section{ATGGC Collection}

Staff at the ATGGC have actively collected wild relatives of tropical crop and forages from northern Australia since 1994. To date, eight collecting missions have been undertaken over $12 \mathrm{yr}$, which have collected a large number of Australian native Gossypium collections. The ATGGC 
Table 1. Description of the cultivated tetraploid species in present in eight major cotton germplasm collections.

\begin{tabular}{|c|c|c|c|c|c|c|c|c|}
\hline \multirow[b]{2}{*}{ Species } & \multicolumn{8}{|c|}{ Collection } \\
\hline & Australia & Brazil & China & CIRAD $^{\dagger}$ (France) & India & Russia & United States & Uzbekistan \\
\hline \multicolumn{9}{|l|}{ G. hirsutum L. } \\
\hline Germplasm & 921 & 219 & 5898 & & 7484 & 655 & & \\
\hline Cultivars & 595 & & 490 & 1426 & 110 & 2513 & 3780 & 12,315 \\
\hline Landraces/wild stocks & 2 & $951 / 490$ & $220 / 350$ & 747 & 7 & $1067 / 48$ & 2522 & 727 \\
\hline Cytogenetic stocks/mutants & & & $37 / 717$ & & $32 / 1$ & $5 / 10$ & & 199 \\
\hline Unclassified & & & & & & 204 & & \\
\hline Total no. & 1518 & 1660 & 7712 & 2173 & 7633 & 4503 & 6302 & 13,241 \\
\hline \multicolumn{9}{|l|}{ G. barbadense L. } \\
\hline Germplasm & 51 & 1470 & 553 & & 530 & 260 & 317 & 11 \\
\hline Cultivars & 45 & & 50 & 214 & 3 & 603 & 105 & 2999 \\
\hline Landraces/wild stocks & 3 & 39 & $19 / 0$ & 269 & $1 / 0$ & $132 / 35$ & 175 & $7 / 1$ \\
\hline Cytogenetic stocks/mutants & & & 11 & & & & & $0 / 1$ \\
\hline Unclassified & 5 & & & & & 27 & 987 & \\
\hline Total no. & 104 & 1509 & 633 & 483 & 534 & 1057 & 1584 & 3019 \\
\hline
\end{tabular}

†CIRAD, Centre de Coopération Internationale en Recherche Agronomique pour le Développement.

collection consists of 1080 accessions covering 28 Gossypium species. Ninety percent of the ATGGC collection comprises G. hirsutum accessions and the remainder consists of the other four tetraploid species and additional diploid species originating from 22 different countries.

All germplasm collections at ATGGC are maintained under long-term conditions where germplasm are preserved as seed that is dried to $6 \%$ moisture content in a dehumidified room operating at $15^{\circ} \mathrm{C}$ and $15 \%$ relative humidity. Once the seed is dry, it is sealed in laminated aluminum bags and stored at $-20^{\circ} \mathrm{C}$. Under these conditions, seed of most crop species will remain viable for $>50$ yr. In the past, when funding was available, all ATGGC accessions were routinely monitored for germination every $10 \mathrm{yr}$ and regenerated if germination fell below a predetermined level (specific to genus and species). Seed was regenerated either in the field in a suitable location, or in the glasshouse with controlled pollination (where required) and appropriate seed harvest techniques.

Germplasm was extensively characterized in the past, but no current characterization work is being undertaken. Previously, plant and seed morphologies were characterized. The ATGGC maintains an in-house seed management database that manages germplasm passport, collection, characterization, inventory, seed health, germplasm regeneration, and seed distribution data. The passport, characterization, and collection data are freely available via the Australian Plant Genetic Resources Information System Web site (AusPGRIS; http://www.dpi.qld.gov.au/auspgris [verified 27 Mar. 2010]). The AusPGRIS Web server is managed by Department of Employment, Economic Development and Innovation, Queensland, Australia. Small quantities (20-30 seeds per accession) of germplasm and the associated passport data are freely available to researchers worldwide through the AusPGRIS Web site. A current national review of Plant Genetic Resource Centres in Australia will see the replacement of the AusPGRIS Web site with GRIN-Global, the newly developed germplasm management database as the public access website for cotton germplasm; however, this will not be in place until late 2010. The national restructure of the Australian Plant Genetic Resource Centres will not interfere with the public access or maintenance of the cotton germplasm collections.

\section{Brazil}

Cotton is a traditional and important crop in Brazil. According to the World Bank, from 2005 to 2007, Brazil produced between 4.7 and 7.4 million bales of cotton. During the last century, cotton was cultivated in two primary regions, including the semiarid northeastern states where perennial forms of G. hirsutum race 'marie-galante' were grown and the more humid states in the southeast where Upland cotton was grown. At the end of the 1980s, economical and social changes occurring concomitantly with the introduction of the boll weevil, rendered nonviable cotton production in these areas. At the same time, agriculture in Brazil was expanding toward the Cerrado region (Brazilian savanna) and cotton was tested as one of the alternatives to develop crop rotation systems associated with soybean [Glycine $\max (\mathrm{L}$.) Merr.] production. Climate and crop production system differences compared with that of previous cotton-growing regions made it necessary to develop cultivars specific to the Cerrado, with higher yield potential and enhanced levels of disease resistance. To reach this goal, national public and private breeding programs made use of imported and local germplasm. As a result, the cultivated area expanded in 2007 and 2008, where cotton was planted on approximately 1 million ha, with an average lint yield slightly superior to 1.5 tons $\mathrm{ha}^{-1}$. The level of resistance to some of the most important diseases is still below the necessary, and germplasm screening efforts are being made to identify new sources of resistance. 
Table 2. Description of the wild primary, secondary, and tertiary cotton (Gossypium) species present in eight major cotton germplasm collections.

Collection

Species

Genome Australia Brazil China $\mathrm{CIRAD}^{\dagger}$ (France) India Russia United States Uzbekistan

Primary gene pool

G. tomentosum Nuttall ex Seemann

G. mustelinum Miers ex Watt

G. darwinii Watt

Secondary gene pool

G. herbaceum L.

G. arboreum L.

G. anomalum Wawra

G. triphyllum (Harvey \& Sonder) Hochreutiner

G. capitis-viridis Mauer

G. barbosanum Phillips \& Clement

G. longicalyx J. B. Hutchinson \& Lee

G. thurberi Todaro

G. trilobum (DC) Skovsted

G. davidsonii Kellogg

G. Klotzschianum Andersson

G. armourianum Kearney

G. harknessii Brandegee

G. turneri Fryxell

G. aridum (Rose \& Standley) Skovsted

G. lobatum H. Gentry

G. laxum Phillips

G. schwendimanii Fryxell \& S. Koch

G. gossypioides (Ulbrich) Standley

G. raimondii Ulbrich

Tertiary gene pool

G. sturtianum J. H. Willis

G. robinsonii F. Mueller

G. nandewarense (Derera) Fryxell

G. benadirense Mattei

G. bricchettii (Ulbrich) Vollesen

G. vollesenii Fryxell

G. stocksii Masters in Hooker

G. somalense (Gurke) J. B. Hutchinson

G. areysianum Deflers

G. incanum (Schwartz) Hillcoat

G. australe F. Mueller

G. nelsonii Fryxell

G. bickii Prokhanov

G. costulatum Todaro

G. cunninghamii Todaro

G. exiguum Fryxell, Craven \& Stewart

G. rotundifolium Fryxell, Craven \& Stewart

G. enthyle Fryxell, Craven \& Stewart

G. nobile Fryxell, Craven \& Stewart

G. pilosum Fryxell

G. pulchellum (C. A. Gardner) Fryxell

G. londonderriense Fryxell, Craven \& Stewart

G. marchantii Fryxell, Craven \& Stewart

G. populifolium (Bentham) F. Mueller ex Todaro

G. anapoides Stewart, Wendel \& Craven

$\begin{array}{llr}\mathrm{AD}_{3} & 6 & 10 \\ \mathrm{AD}_{4} & 1 & 16 \\ \mathrm{AD}_{5} & 1 & 4\end{array}$

1
1
1

2
1
95

$\begin{array}{lllll}\text { A } & 3 & 19 & 18 & 50\end{array}$

$\begin{array}{lllll}A_{2} & 25 & 219 & 433 & 69\end{array}$

$\mathrm{B}_{1}$

69

$\mathrm{B}_{2}$

20

$\begin{array}{lllll}\mathrm{B}_{3} & - & 3 & 1 & 3\end{array}$

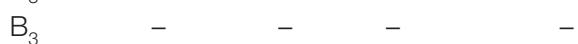

$\mathrm{F}_{1}$

$D_{1}$

$\mathrm{D}_{8}$

$D_{3-d}$

$\mathrm{D}_{3-k}$

$D_{2-1}$

$\mathrm{D}_{2-2}$

$\mathrm{D}_{10}$

$\mathrm{D}_{4}$

$\mathrm{D}_{7}$

$\mathrm{D}_{9}$

$D_{11}$

$\mathrm{D}_{6}$

$\mathrm{D}_{5}$

3
383

-

$\begin{array}{lll}143-1 & 3\end{array}$

4

45

3

3

1

C. 14

$19-1$

$\begin{array}{rrrr}1 & 1 & 16 & 1 \\ - & - & 19 & 1 \\ 1 & - & 138 & 1\end{array}$

$\begin{array}{rrrr}282 & 336 & 194 & 1495 \\ 1943 & 365 & 1729 & 1185 \\ 1 & - & 7 & 1 \\ 1 & 1 & 2 & 1\end{array}$

$\mathrm{C}_{2}$

$\mathrm{C}_{1 \mathrm{~N}}$

E

$E_{1}$

$\mathrm{E}_{2}$

$\mathrm{E}_{2}$

$\mathrm{E}_{4}$

G

$\mathrm{G}_{3}$

$K_{1}$

$\mathrm{K}_{1}$

$\begin{array}{llll}\mathrm{K}_{8} & - & - & - \\ \mathrm{K}_{12} & - & - & -\end{array}$

$\mathrm{K}_{12}$

$\mathrm{K}_{7}$

$K_{11}$

$K_{5}$

$\mathrm{K}_{4}$

$\mathrm{K}_{9} \quad-$

$\begin{array}{rr}19 & 1 \\ 4 & 1 \\ 2 & 1\end{array}$

2

1

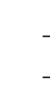

$-$

$-$

† CIRAD, Centre de Coopération Internationale en Recherche Agronomique pour le Développement. 


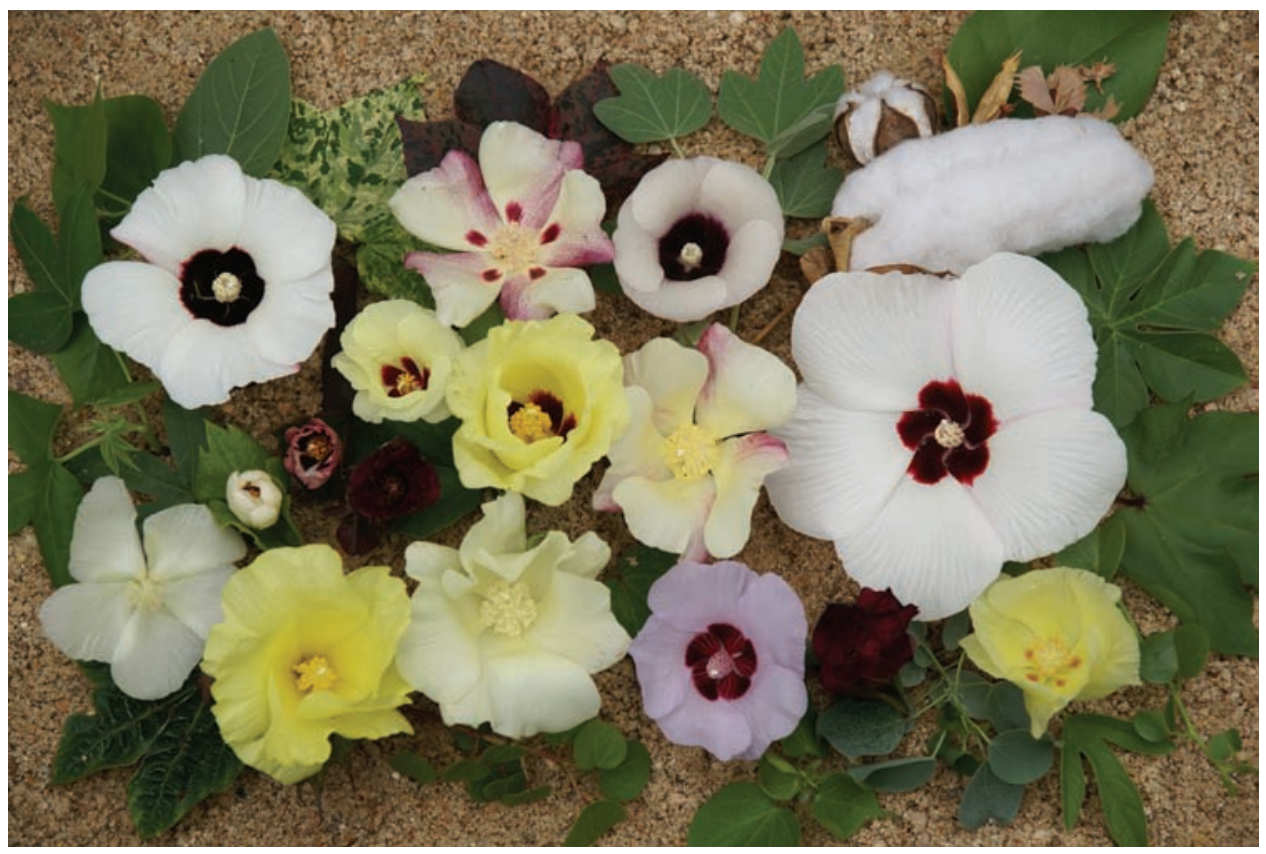

Figure 1. A portion of the flower diversity present in Gossypium spp. germplasm resources.

The Brazilian collection is maintained by the Brazilian Agricultural Research Corporation (Embrapa) at the National Center for Genetic Resources and Biotechnology. In 1974, the same year when CGIAR created the International Plant Genetic Resources Institute (IPGRI), Embrapa in Brazil created a research unit called the National Center for Genetic Resources and Bioetchnology (Cenargen) with the basic mission to coordinate the appropriate means of management of the genetic resources of the country. The base collection (Colbase) of cotton germplasm collection is housed at Embrapa Cenargen. The Brazilian collection at Embrapa is funded internally with resources appropriated by the Ministry of Agriculture, Livestock and Food Supply. The long-term maintenance of the collection is supported with Embrapa public resources. Three research geneticists are actively involved with germplasm collection and maintenance. In addition, several professionals, including three phytopathologists, two entomologists, one plant physiologist, one plant breeder, two nematologists, and one seed technologist, also support the evaluation process of cotton germplasm.

In Brazil, there are about 4361 cotton germplasm accessions, of which 39\% are G. hirsutum and 35\% G. barbadense. The remaining accessions represent 26 diploid species and the other three tetraploid species. Brazil maintains at Embrapa Cotton 53 accessions of in vivo collections of G. mustelinum Miers ex Watt and 63 accessions of G. hirsutum race 'marie-galante' (mocó cotton), a racestock from Brazil. New accessions are entered into the collection after passing phytosanitary examinations.

In Brazil, there are five available storage chambers with a current capacity to hold 250,000 accessions operating at $-20^{\circ} \mathrm{C}$ and $5 \pm 2 \%$ of water content for long-term seed storage. However, this facility provides storage for the genetic resources of an array of crops other than cotton. Seed germination is evaluated when accessions are incorporated to the collection and viability tests are conducted after every $10 \mathrm{yr}$. If germination is $<85 \%$ or the accession is represented by a few seeds, seed multiplication and regeneration is performed in gene bank (BAG-centers) where active collection germplasm are stored (http:// www.fao.org/AG/AGp/agps/pgrfa/pdf/brazil.pdf [verified 28 Mar. 2010]).

Until 2006 cotton germplasm was evaluated according to agronomical, morphological, and fiber traits using a protocol adapted from the International Union for the Protection of New Varieties of Plants (UPOV). As of 2007, evaluations for resistance to drought stress, fungi, and bacterial and nematode diseases are also performed. The evaluations are performed at semiarid and savannah conditions in Brazil. The germplasm information is maintained in two databases named Sibrargen and Albrana. Albrana was created through a project funded by the Brazilian Ministry of Environment and contains a portion of the data collected during recent expeditions since 2002 . These data include information about geographic, environment, in situ maintenance conditions, and some morphological traits. These data are freely accessible at https:// www.cnpa.embrapa.br/albrana/ (verified 28 Mar. 2010).

Over time, the Brazilian germplasm collection has grown through numerous germplasm exploration expeditions. Many explorations for cotton were performed by the Instituto Agronômico de Campinas during the 1960s. Gossypium mustelinum was rediscovered as native to Brazil and G. barbadense was collected from the savanna, coastal, and semiarid regions during these expeditions (Neves et al., 
1965, 1968). The Instituto Agronômico de Pernambucano and University of Reading (United Kingdom) performed expeditions to the Northeast region during 1970s. Two new populations of G. mustelinum were found and several new accessions of G. barbandense and G. hirsutum race 'mariegalante' (mocó cotton) were collected during this expedition (Pickersgill et al., 1975). During the 1980s, Embrapa performed several field expeditions, mainly to the Northeast region of Brazil, one of them in collaboration with USDA-ARS in 1988. Twenty-six short-duration explorations (between 6 and $15 \mathrm{~d}$ ) have been performed since 2002 to 24 of 27 states in Brazil. During the explorations, 1848 new accessions were collected and some new populations of G. mustelinum, native to Brazil, were identified (Barroso et al., 2009; Almeida et al., 2009). There are plans for new expeditions to explore other new G. mustelinum populations and to collect G. barbadense and mocó cotton from the three states not previously included.

Seed of germplasm can be requested following several steps described in Portuguese at the Embrapa Cenargen homepage (www.cenargen.embrapa.br [verified 28 Mar. 2010]). Seed is available on an executed Material Transfer Agreement and phytosanitary certificate.

\section{China}

China is the largest producer and consumer of cotton in the world. According to the World Bank, from 2005 to 2007, China produced 28.4 to 37 million bales of cotton and consumed 45 to 51.5 million bales in the country's domestic textile mill industry. On average, cotton is produced on $\sim 5.6$ million ha in China within three predominant growing areas, including Xinjiang, the Yellow River, and the Changjiang River. Similar to India, China's adoption of Bt hybrids and cultivars have resulted in marked yield increases in recent years.

The Chinese cotton germplasm collection is housed by the Chinese Academy of Agricultural Sciences in Beijing, Anyang, and Hainan Island. A working collection is housed at Anyang, a long-term collection at Beijing, and an in vivo collection of wild species at Hainan Island. Funding for maintenance of the collections is provided through the Chinese government through the National Key Technology Research and Development Program, the National Key Basic Research and Development Program, the National Science Foundation of China, the Ministry of Science and Technology, and the Ministry of Agriculture. There are five full-time staff members assigned to the maintenance and conservation of the germplasm collection. The total collection consists of 8868 accessions that represent cultivated species (G. arboreum L., G. herbaceum L., G. hirsutum, G. barbadense) and 41 wild species.

Seven thousand two-hundred twenty-one accessions are preserved long term in Beijing at $-18^{\circ} \mathrm{C}$ and $57 \%$ relative humidity. The collection in Anyang, considered the working collection, contains 8344 accessions and is maintained at $0^{\circ} \mathrm{C}$ and $50 \%$ relative humidity. The Hainan Island storage site maintains an in vivo collection of 391 wild species and G. hirsutum racestock accessions in a garden under natural field conditions. Over time, the Chinese collection has increased through international germplasm exchange and exploration. Past germplasm explorations have covered much of southern China (Hainan Island, Guangxi, and Guangzhou) and the mountainous areas of Yunnan and west Sichuan provinces primarily for G. arboreum. Gossypium hirsutum racestock germplasm has also been collected from southern Mexico. Seed of germplasm accessions in the working collection are renewed according to individual accession germination rates using forced self-pollination. When germination rates fall $<65 \%$, accessions are increased and renewed.

Germplasm accessions are evaluated by field investigation according to the established and published Descriptors and Data Standards for Cotton Germplasm based on IPGRI description standards. Agronomic, fiber quality, seed quality, stress resistance, disease resistance, and insect resistance data are collected for each accession. The Chinese Crop Germplasm Information System (CGRIS) serves as a central repository for all germplasm accession characterization and evaluation information for China and is freely available (http://icgr.caas.net.cn/cgrisintroduction.html [verified 28 Mar. 2010]). Cotton germplasm evaluation and characterization data are first stored on an offline, internal database and then periodically deposited into the CGRIS online database.

Official germplasm seed requests within China are made to the Cotton Research Institute of the Chinese Academy of Agricultural Sciences. A Material Transfer Agreement is required to distribute seed of requested germplasm. Seed requests from outside of China require a complex procedure for approval.

\section{France}

The French cotton germplasm collection is housed by the French Centre de Coopération Internationale en Recherche Agronomique pour le Développement (CIRAD) in Montpellier, France. The CIRAD is a French publicly supported agency that specializes in tropical and Mediterranean agriculture under the authority of the Ministry of Higher Education and Research and the Ministry of Foreign and European Affairs. Although cotton is not domestically produced in France, CIRAD actively conducts research and maintains a cotton collection because cotton is produced in tropical and subtropical areas of the world. The French cotton germplasm collection, better known as the CIRAD Cotton Germplasm Collection, is funded by CIRAD and the primary germplasm collection site in Montpellier is supported by two full-time, salaried employees. One additional full-time employee is supported abroad. Dessauw and Hau (2006) provide an excellent description of the history 
of the CIRAD collection. Briefly, the collection contains 3070 accessions representing five tetraploid species and 27 diploid species. The accessions are organized according to species, geographical and ancestral origin. The cultivated species are separated according to whether they are cultivated or ancestral forms. Long-term and working subsets of the entire collection are preserved in Montpellier. Longterm seed storage is performed under $-18^{\circ} \mathrm{C}$ conditions, whereas a working collection is maintained at $4^{\circ} \mathrm{C}$ and $40 \%$ relative humidity.

The CIRAD Cotton Germplasm Collection has evolved and grown over time through Bioversity International (FAO)-sponsored germplasm explorations covering Central America, South America, and parts of Africa. Germplasm has also been placed into the CIRAD collection through exchanges with other countries, or collections donated by partners, including the Royal Botanic Gardens, Kew (United Kingdom) and the Universite des Sciences agronomiques de Gembloux (Belgium). Additional germplasm explorations, not funded by Bioversity International, have also contributed to the current CIRAD collection. However, no additional germplasm explorations are planned for the near future.

Seed supplies of accessions are renewed every 12 to $15 \mathrm{yr}$ using forced self-pollination in nurseries grown in tropical or subtropical regions outside of Europe. Cultivated accessions are renewed every $12 \mathrm{yr}$ and wild species every 15 yr. In a given year, 250 accessions are systematically renewed to spread the seed production. Wild species that prove difficult to grow are renewed under greenhouse conditions in Montpellier.

The cultivated germplasm accessions are characterized during seed renewal outside of Europe according to guidelines established by CIRAD. Data include management parameters, material identifiers (passport data), qualitative characteristics (resistance to biotic or abiotic stress), and numerous criteria concerning quantitative traits. These data include 33 morphological parameters and 31 seed, fiber, and yarn parameters. Cultivars are also evaluated for yield and earliness. While evaluating the accessions of the cultivated species, permanent controls are simultaneously evaluated for G. hirsutum (cv. Deltapine 61), G. arboreum, G. herbaceum, and G. barbadense (cv. Giza 75). Wild species and landraces are evaluated for four additional characteristics, including the number of teeth on the bract, pistil division, stamen arrangement, and style position. All data collected on germplasm accessions are housed in an agency-maintained database. There are numerous examples of CIRAD germplasm utilization in tropical countries of the world. Upland cotton cultivars grown in Côte d'Ivoire and Togo were developed using CIRAD trispecies hybrids (G. hirsutum $\times G$. arboreum $\times G$. raimondii Ulbrich; e.g., cv. L299-10) and from crosses involving CIRAD accessions with accessions from the United States, Asia, and Africa (cv. ISA 205 and cv. STAM F). In addition, cultivars grown in Paraguay and Argentina (cv. Reba B50, cv. Reba P279, and cv. Gringo) were developed from crosses using CIRAD accessions. Seeds of germplasm accessions acquired as part of the Bioversity Internationalfunded explorations are freely available on request and agreeing to a Material Transfer Agreement with CIRAD. Seed accessibility for cultivars is managed according to the UPOV regulations. Obsolete cultivars in the public domain are freely available on agreeing to a Material Transfer Agreement with CIRAD. Protected cultivars jointly developed with CIRAD are available through specific agreements. Protected cultivars that are not jointly developed with CIRAD are not available.

\section{India}

In India, cotton is a major agricultural commodity and a large part of the Indian economy. According to the World Bank, India is the second largest producer and consumer of cotton. From 2005 to 2007, India produced 19 to 25 million bales of cotton, while consuming 16.7 to 18.3 million bales in the domestic textile mill industry. On average, cotton is produced on 9.8 million ha and represents all four cultivated species (G. hirsutum, G. barbadense, G. arboreum, and G. herbaceum). India represents the only cottonproducing country that cultivates all four cultivated species of cotton. In total, cotton production contributes to 30\% of the Indian Agricultural Gross Domestic Product and accounts for $30 \%$ of all export earnings. Over a 6 -yr period from 2002 to 2008 , cotton productivity has doubled from 15 million to 31 million bales, with an annual average lint yield of $553 \mathrm{~kg} \mathrm{ha}^{-1}$. The increase in productivity is mainly attributed to the introduction of $>200 \mathrm{Bt}$-cotton hybrids as well as some new conventional hybrids.

The Indian cotton germplasm collection is maintained as a working collection by the Central Institute for Cotton Research (CICR) at Nagpur and Coimbatore and as a permanent storage collection at the National Bureau for Plant Genetic Resources (NBPGR) in New Dehli. Funding for the CICR and the NBPGR is provided by the Indian Council for Agricultural Research that is an autonomous organization of the Indian Ministry of Agriculture's Department of Agricultural Research and Education. In total, there are eight scientists, eight technical staff, and four supporting staff positions assigned to the cotton germplasm collection at CICR and NBPGR. The total collection consists of 10,227 accessions that represent almost entirely cultivated accessions of G. hirsutum, G. barbadense, G. arboreum, and $G$. herbaceum. In addition, the collection also consists of racestock accessions of each cultivated species, 26 wild species, and 32 synthetic introgressed derivatives.

Long-term storage of cultivated species are housed at the NBPGR in New Dehli and maintained at $-40^{\circ} \mathrm{C}$. A working collection of all cultivated accessions, excluding the G. barbadense accessions, is stored at Nagpur and maintained at $4^{\circ} \mathrm{C}$. The G. barbadense accessions are stored 
at Coimbatore and maintained at $4^{\circ} \mathrm{C}$. Wild species and racestock working collections are exclusively stored at Nagpur in vivo under natural field conditions. Seed of germplasm accessions are renewed by planned seed increases that include forced self-pollination.

Since 1960, the Indian collection has grown with the establishment of the Indian Central Cotton Committee, the All India Coordinated Cotton Improvement Project, and the Central Institute for Cotton Research. In 1976, the Central Institute for Cotton Research was established with a mandate to function as National Centre for Cotton Genetic Resources collection, documentation, and utilization. Regular collection expeditions were organized by the National Germplasm Centre in collaboration with the NBPGR in various parts of the country. In recent years, plant explorations have covered a large part of India, and several plant exploration trips are planned through 2010. These include exploration of Mizoram, Sundarban (West Bengal), Assam (Kamroop hills and Jayanti hills), Meghalaya (east Garo Hills), and Tripura. The collection has also grown through exchange with the United States, France, Uzbekistan, and Czechoslovakia. The FAO-organized germplasm expeditions also provide opportunities to expand the germplasm collection.

Evaluation and characterization of cultivated germplasm accessions are performed based on the cotton descriptors and index card developed by IPGRI and supplemental guidelines supplied by NBPGR. Types of evaluation and characterization of cultivated germplasm include morphological, taxonomical, yield, and yield-contributing characters, fiber quality parameters, and reaction to biotic and abiotic stresses. Basic studies are also performed on the structural variation of gossypol and nectar glands, pollen grains, stigma receptivity, cytogenetic studies, and cross-compatibility among various species (wild and cultivated). Accessions of G. hirsutum and G. arboreum are evaluated in multilocation evaluation trials conducted at three locations within India (Sirsa, North zoneirrigated; Nagpur, Central zone-rainfed; and Coimbatore, South zone-irrigated). Accessions are evaluated for yield, boll weight, gin turnout, fiber properties, and reaction to pests and diseases, and promising genotypes are distributed to breeders and researchers at various Cotton Research Stations and Government Institutions within India for research purposes only. Germplasm accession data are housed locally by the NBPGR and data are freely available only to Indian government organizations.

Official germplasm seed requests are made through NBPGR and a special application form is required to procure exotic germplasm. The NBPGR then determines if a Material Transfer Agreement is already available with the requesting country and makes the necessary correspondence. The seed material is subsequently distributed through NBPGR and Central Institute for Cotton Research on the basis of the request.

\section{Russia}

Before the dissolution of the Union of Soviet Socialist Republics (USSR) in 1991, Russia was a primary center of cotton textile manufacturing for the cotton grown in Central Asia. Although over the course of history cotton has not been produced in Russia, the former USSR continues to represent a major worldwide source of cotton production and export. Following the establishment of independent republics, the former USSR cotton-producing countries of Central Asia, including Uzbekistan, Turkmenistan, Kazakhstan, Tajikistan, and Azerbaijan, have continued producing and exporting large amounts of cotton. According to the World Bank, from 2005 to 2007 , these countries produced a combined 8.0 to 8.2 million bales of cotton. In addition, raw cotton exports combined across these countries over the same 3 -yr period ranged from 6.4 to 7.1 million bales.

In the former USSR, cotton germplasm resources were first collected, organized, and maintained by Nikolai Vavilov in the early 20th century. By 1924, coordinated efforts were established to store and maintain these collections at the All-Union Institute of Applied Botany and New Crops at Leningrad, Russia, retaining its structural autonomy within the State Institute of Experimental Agronomy (SIEA). In 1930, the department of Applied Botany and New Crops and the department of Plant Breeding at SIEA were merged to form the All-Union Institute of Plant Industry. This institute is now named the N.I. Vavilov Institute of Plant Industry (VIR) and consists of 9 plant genetic resources departments, 13 fundamental research laboratories, and 12 experiment stations in different geographic zones of Russia, with the responsibility to maintain 320,000 accessions of 155 botanical families and 2532 species of 425 genera that include cotton.

The current Russian cotton germplasm collection, better known as the VIR collection, is housed at VIR in St. Petersburg and consists of 6322 accessions comprised of 24 diploid species, 3 tetraploid species, and several diploid and tetraploid hybrids. Cultivated types include accessions of G. arboreum, G. herbaceum, G. hirsutum, and $G$. barbadense. Seventy percent of the VIR collection is represented by G. hirsutum cultivars, landraces, and germplasm lines. Somewhat unique to Russia, the VIR cotton collection contains approximately 100 colored fiber accessions of all cultivated species from several different countries. The accessions produce cream-colored, golden, orange, reddish, brown, dark brown, and green fiber. The most interesting genotypes are wild perennial forms of G. barbadense from Peru that possess a whole spectrum of colored fibers, including pink and lilac colored.

The VIR collection is maintained under short-term conditions at $4{ }^{\circ} \mathrm{C}$ and $6 \%$ relative humidity, while longer term conditions are $-10^{\circ} \mathrm{C}$ and $3.5 \%$ relative humidity. Seed renewals of cultivated Gossypium species are systematically performed under forced self-pollination at dryland 
and irrigated field conditions at two agricultural experiment stations that include the VIR Astrakhan Experiment Station (irrigated) in Astrakhan and the Stavropol Agricultural Institute (dryland) in Budyonnovsk. Seed of wild Gossypium species and G. barbadense accessions are replenished under greenhouse conditions. Three full-time scientists and four technical support employees are funded through support from the VIR and are responsible for maintaining and preserving the VIR cotton collection. Technical support of the cotton collection consists of one scientist and one technical support employee located at the VIR main preservation center, one scientist and two technical support employees located at the VIR Astrakhan Experiment Station, and one scientist and one technical support employee located at the Stavropol Agricultural Institute.

Passport data are available for the majority of accessions in the VIR collection. A subset of more recently added accessions also include morphological and agronomic trait data such as plant height, number of sympodial nodes, boll number, boll weight, gin turnout, fiber length, and seed mass. A very select number of cultivated accessions contain high-volume instrument fiber data. A locally accessible computer database is used to store accession data collected since the dissolution of the USSR. Data before the dissolution of the USSR are maintained by written records.

Primarily through the efforts initiated by Nikolai Vavilov, the official registration of cotton germplasm accessions began in 1922, but several accessions were collected before 1916. By 1941, the VIR cotton collection consisted of $>3000$ germplasm accessions and represented G. hirsutum, G. barbadense, G. herbaceum, and G. arboreum species. Over its history, the VIR collection has grown through germplasm collection and exchange involving primarily the United States, India, and China. Many accessions originated from the republics of the former USSR. In addition to the efforts of Nikolai Vavilov, N. Lemeshev also collected many local cotton accessions and other cultivated and wild accessions native to Mexico, Brazil, Peru, Costa Rica, the United States, and Australia. The development of early-maturing cotton cultivars has been a goal for Central Asian and European countries, and the VIR collection has provided many accessions originating from Bulgaria, Greece, Yugoslavia, Romania, Albania, and other European countries to provide adaptation to northern climatic zones. Over its history, many of these VIR accessions have been utilized to develop new cultivars with improved fiber quality and early maturity with adaptation to the south of Russia. These cultivars include POSS-1, POSS-2, AS-IV, AS-V, AS-VI, AS-VII, Yugtex-1, Yugtex-2, Goliot, and others. Gossypium hirsutum race 'punctatum' accessions from Mexico have also been used to develop early-maturing cultivars with improved fiber quality. The VIR collection also contains a number of early-maturing dwarf G. barbadense accessions.
Seed of germplasm accessions is freely available to researchers within Russia. Request made by researchers outside of Russia can be made through a written request to the Director of the N.I. Vavilov Institute of Plant Industry. Seed is available on VIR Director approval.

\section{United States}

The United States is a major producer of cotton and historically has ranked as one of the top three producers of cotton worldwide. According to the World Bank and USDANASS, from 2005 to 2007, 19.2 to 23.9 million bales of cotton were produced in the United States, with an estimated value ranging from US $\$ 5.8$ to 6.7 billion. Cotton is produced in 17 states across the southern United States from Virginia to California. Two species of cotton are grown in the United States, G. hirsutum and G. barbadense, with G. hirsutum comprising $>98 \%$ across the production belt and G. barbadense confined to production areas in the arid Southwest, primarily in the states of Texas, New Mexico, Arizona, and California, with California having the majority of the area. Cotton cultivation is synonymous with the early economic development of the United States. The expansion of cotton cultivation into new geographic areas and the onset of destructive pests such as the boll weevil stimulated cotton breeding and germplasm research. The importance of cotton germplasm research was recognized at the government, industry, and university levels.

The USDA opened the Plant Introduction Office in 1898 and sponsored plant exploration and germplasm research. United States-sponsored cotton germplasm explorations date back to the early 1900s (Percival and Kohel, 1990; USDA-ARS, 1977). Since 1985, 12 acquisition trips have been made by U.S. scientists to collect germplasm. Ten of the trips were used for in situ explorations, while two trips were used to collect germplasm held ex situ by other countries. Two trips were conducted to exchange germplasm with India, China, Russia, and Uzbekistan, respectively (Wallace et al., 2009). The most recent exploration trip was conducted in the western states of Mexico (Ulloa et al., 2006).

Accordingly, Plant Introduction centers were established with the Agricultural Marketing Act of 1946 and a National Seed Storage Laboratory (now the National Center for Genetic Resources and Preservation [NCGRP]) was established in 1958 for long-term backup storage of germplasm. Cotton breeders and scientists from university and state experiment stations also assembled cotton germplasm collections. Collaborative U.S. regional projects involving scientists and members from all aspects of the U.S. cotton industry coordinated cotton research programs spanning cytology, genetics, breeding, fiber quality, and production research. The first Regional Research Project was S-1 in 1950 (succeeded by many, e.g., S-77, S-304, and recently SDC-317) and it established a priority 
of acquiring and studying diverse germplasm for cotton improvement (USDA, 1956). A key outcome of this collaborative, regional project led to the establishment of extensive cotton germplasm collections at three sites: Phoenix, AZ (G. barbadense); Stoneville, MS (G. hirsutum cultivars); and Texas A\&M University, College Station (species, landraces, and genetic stocks) (Percival, 1987).

In 1960, these collections were deposited at NCGRP with their passport data to form the basis of the U.S. cotton germplasm collection as it exists today. Descriptor data evolved over time with each collection, but the IPGRI established a set of cotton descriptors in 1980 to serve as a data collection guide for data collection for the U.S. and other collections (IBPGR Secretariat, 1985). The U.S. cotton germplasm collection has continued to grow over time through publicly donated cultivars and germplasm lines, germplasm exchange with other countries, and/or germplasm exploration. The National Plant Germplasm System (NPGS) represented these activities in cotton and other major crops and was formally recognized by USDA-ARS, which committed recurring federal funds for continued plant exploration, formal exchanges with other collections, curatorial activities of the collection, and seed storage facilities for crop germplasm.

Currently, nearly 10,000 accessions covering 45 Gossypium species are maintained in the National Collection of Gossypium. Germplasm are distributed worldwide and the collection is subdivided into seven different parts: (i) variety collection, (ii) primitive landrace collection, (iii) G. barbadense collection, (iv) Asiatic (A-genome species) collection, (v) wild species collection, (vi) genetic marker collection, and (vii) a base collection (i.e., NCGRP) of all materials in Parts 1 to 6 and new plant introductions (Percival et al., 1999). Parts 1 to 5 constitute the "working collection," which is routinely seed propagated and distributed by the USDA-ARS at College Station, TX. The working collection is maintained at $4.5^{\circ} \mathrm{C}$ and $23 \%$ relative humidity. Part 7 is housed at the NCGRP in Fort Collins, $\mathrm{CO}$, under conditions more favorable for longterm storage $\left(-18^{\circ} \mathrm{C}\right)$ and serves as a reserve and backup for the working collection.

Seed supplies of the working collection are primarily replenished and increased at the Tecoman Winter Nursery (Tecoman, Colima, Mexico) that is administered and operated jointly with the National Cotton Council through a Specific Cooperative Agreement with the USDA-ARS. A small portion of seed supplies are increased at College Station. All seed increased in Tecoman or College Station under field conditions undergo forced self-pollination. Some wild species accessions that prove difficult to manage under field conditions (e.g., highly exerted stigmas or perennial growth habits) are grown in greenhouses. Each year, approximately $10 \%$ of the working collection (i.e., approximately 1000 accessions) seed stocks are regenerated; thus, each accession is replenished every $10 \mathrm{yr}$.
Germplasm accessions are characterized following the 1980 descriptor sets of the IPGRI and recommendations of the Cotton Crop Germplasm Committee, which also formulates regular status reports of the cotton collection and crop vulnerability status (Wallace et al., 2009). Data formally collected for each accession are stored in the national Germplasm Resources Information Network (GRIN) database and are freely accessible to anyone via the Internet at http://www.ars-grin.gov/ (verified 28 Mar. 2010).

The diverse germplasm present in the U.S. collection has been critical for cotton breeding research focused on cultivar and germplasm development, as well as basic genetic, physiology, and production studies. A few examples of contributions that the collection has made to cotton improvement efforts follow. The landrace and diploid species were found to possess useful genetic diversity (Dilday and Shaver, 1976; Kohel, 1978; Fryxell, 1976), but most are photoperiodic and require conservation in situ or special care in greenhouses or winter nurseries. Germplasm accessions present in the U.S. collection were also used to develop trispecies hybrids that allowed breeders to transfer increased fiber-strength genes from the D-genome diploid species G. thurberi Todaro to Upland cotton (Beasley, 1942). Several breeding programs, including the Pee Dee and New Mexico Acala, utilized these materials to develop cultivars and germplasm lines with increased fiber strength (Campbell et al., 2009). In addition, recently, G. longicalyx J. B. Hutchinson \& Lee, a wild, diploid species, was used to transfer reniform nematode resistance into Upland cotton (Robinson et al., 2007). This utilization of wild germplasm provides breeders a real opportunity to develop new cultivars with reniform nematode resistance and environmental adaptation.

The NPGS mandates that anyone with a bona fide interest in cotton and an import permit (where required) can request seeds from the USDA-ARS collection through GRIN. The current collection is not under Material Transfer Agreements and is in high demand abroad and worldwide. Yearly distributions amount to $>2000$ accessions in nearly 100 or more orders. Long-term, dedicated support from the USDA-ARS allows for stable maintenance of the collection, continued germplasm exploration/exchanges, and expansion of germplasm processing and storage facilities as needed.

\section{Uzbekistan}

In Uzbekistan, cotton is a primary economic resource, producing and exporting cotton fiber valued at approximately US $\$ 0.9$ to 1.2 billion. According to the World Bank, from 2005 to 2007, an average of 5.5 million bales were produced on a yearly basis. In addition, the Uzbek cotton crop is produced primarily for the export market and represented 22\% of all Uzbek exports from 2001 to 2003.

Cotton germplasm collections in Uzbekistan currently reside in three locations: the Cotton Breeding Institute of 
Agriculture Ministry of Uzbekistan, the Institute of Genetics and Plant Experimental Biology at the Academy of Sciences of Uzbekistan, and the National University of Uzbekistan at Tashkent. Considering all three locations, 50 personnel are assigned to maintaining the Uzbekistan cotton germplasm collections. These three-location cotton germplasm collections are funded by the Ministry of Agriculture, Academy of Sciences of Uzbekistan, and Committee for Coordination of Science and Technology Development under the Cabinet Ministry of Uzbekistan. Additionally, there are small international research grants (e.g., research grants funded within the framework of USDA-Uzbekistan cooperation programs) to facilitate cotton germplasm analysis at the molecular level (Abdurakhmonov et al., 2008a, 2008b).

In total, there are $>20,000$ cotton germplasm accessions available in Uzbekistan including isogenic, inbred lines, recombinant inbred lines (RIL), elite AD allotetraploid varieties (G. hirsutum and G. barbadense), monosomic and translocation lines (A. Abdullaev, personal communication, 2009; Abdukarimov et al., 2003), along with wild, primitive, and extant representatives of the A-toG- and K-genome species. The majority of G. hirsutum wild and cultivar accessions $(\sim 12,000)$ are preserved at the Cotton Breeding Institute of Agriculture Ministry of Uzbekistan (Ibragimov et al., 2008). Approximately 7500 cotton accessions are preserved within the Institute of Genetics and Plant Experimental Biology at the Academy of Sciences of Uzbekistan and represent more than 40 A-to-G- and K-genome wild Gossypium species (also vegetatively maintained at Germplasm Unit greenhouse). These accessions consist of $\sim 4500$ G. hirsutum accessions, 971 G. barbadense accessions, 857 G. herbaceum, and 547 G. arboreum accessions (Abdurakhmonov, 2007), 200 photoperiod-converted mutants of photoperiodic allotetraploid species (Djaniqulov, 2002; Abdurakhmonov et al., 2007), and a number of intra- and interspecific hybrids (Rizaeva, 1996; Abdurakhmonov, 2007). Additionally, $\sim 771$ genetic stocks of $G$. hirsutum consisting of fiber mutants, RIL populations, near-isogenic lines, and cytogenetic stocks are maintained at the National University of Uzbekistan at Tashkent (Musaev et al., 2000; Sanamyan and Rakhmatullina, 2003; Abdurakhmonov, 2007).

In Uzbekistan, there is no facility available for cold storage of germplasm accessions. The collections are maintained under room-temperature conditions. Insufficient funds are available to construct a facility with long-term cold-storage capabilities. Consequently, there is a standard procedure for seed renewal every 8 to 10 yr under forced self-pollination in the field. Accessions are evaluated in every seed renewal period, taking into account at least 56 morphological traits and fiber quality data in Uzbekistan. No written guidelines were developed, but currently the Uzbekistan collection is adopting a policy to implement IPGRI cotton descriptor guidelines.
Molecular characterization of the germplasm collection has also been initiated using microsatellite DNA markers (Abdurakhmonov et al., 2008a, 2008b). All data are stored as a hard-copy catalog book collected from the past $50 \mathrm{yr}$ of evaluation. Collaborative efforts are underway to develop a pcGRIN format database that currently stores all morphological and molecular data for 1000 G. hirsutum accessions (Abdurakhmonov et al., 2006, 2007).

Dr. N. I. Vavilov and F. M. Mauer in 1930 represented pioneers to initiate cotton collection in the former Soviet Union, and their efforts were continued further by Dr. A. Abdullaev's group at the Academy of Sciences of Uzbekistan. During the past $50 \mathrm{yr}$, many scientific expeditions to Australia, China, India, Mexico, Pakistan, Peru, and Sri Lanka led by Dr. Abdullaev, as well as the collaborative efforts of germplasm exchange worldwide, have created a large collection of cotton genetic resources in Uzbekistan. In the early 1960s, A. Abdullaev and F. M. Mauer strongly suggested the potential utilization of wild cotton germplasm, resources as donor lines in cotton breeding programs and experimentally demonstrated its wide utilization in Uzbekistan (Abdullaev et al., 2009). In Uzbekistan, there are numerous examples of germplasm utilization to face production vulnerabilities and develop new cultivars. Landrace germplasm accessions of G. hirsutum have been used to develop adapted cultivars with Fusarium wilt resistance and salt tolerance (Abdukarimov et al., 2003; Abdurakhmonov, 2007; Ibragimov et al., 2008). In addition, wild D-genome cotton accessions were used to develop a naturally early leaf defoliating Upland line through introgression of the trait of interest from wild D-genome diploid cotton species (Rizaeva, 1996; Rizaeva et al., 2001; Abdurakhmonov et al., 2005).

Within the country, any germplasm resource deposited to any of three germplasm collections is openly available for cotton breeders and distributed by bilateral agreements and registration policies. The germplasm curator is responsible for seed sharing and distribution within the country. A Material Transfer Agreement and proper phytosanitary certificate are required to distribute seed of requested germplasm between countries with the restriction of "research purposes only." No germplasm is sent under agreement of "commercial use" or to any private company. A request with proper "research purpose only" justification should be sent to germplasm curators, and on agreement and review of the National Coordinator of Plant Genetic Resources of Uzbekistan, the Ministry of Agriculture of Uzbekistan approves an exchange of the material under Material Transfer Agreement. In the past, Uzbekistan has exchanged cotton germplasm resources with USDA-ARS within the framework of aforementioned cooperative research grants between the USDA and Uzbekistan (Abdurakhmonov, 2007; Abdurakhmonov et al., 2008a, 2008b). 


\section{CONCERNS AND FUTURE PROSPECTS OF THE GLOBAL COTTON GERMPLASM RESOURCES}

Germplasm collections currently face many challenges and opportunities in all primary activities of acquisition, conservation, characterization, and documentation of the germplasm resources they contain. In past years, collections have been successful in expanding their resources through acquisition-either by collecting in native habitat or through exchange efforts. Despite these successes, this report highlights some gaps and deficiencies in our global resources. Several species are not currently conserved within the germplasm collections described in this report. In addition, there are numerous underrepresented species that consist of very few accessions. Table 2 highlights the species that are not represented or are underrepresented. Species that are not conserved include the E-genome species G. benadirense Mattei, G. bricchettii (Ulbrich) Vollesen, G. vollesenii Fryxell, and the K-genome species G. anapoides Stewart, Wendel \& Craven. In particular, the majority of K-genome species are represented by fewer than five accessions, while G. barbosanum Phillips \& Clement $\left(\mathrm{B}_{3}\right)$ and G. schwendimanii Fryxell \& S. Koch $\left(\mathrm{D}_{11}\right)$ are also underrepresented. Correcting these deficiencies in collections has become increasingly more difficult. Species are being threatened by habitat loss, due primarily to conversion of wildlands to agricultural use (Rubenstein et al., 2005). Landrace or dooryard cottons, another source of genetic variation, have frequently been grown in subsistence or basic economies. The adoption of a modern cotton industry has often led to their abandonment in favor of improved cultivars (Singh et al., 2003). Habitat loss and potential species loss are lending an urgency to collecting efforts that has not previously existed. The recent germplasm exploration trip to western Mexico described by Ulloa et al. (2006) describes the alarming effects of habitat loss. In that report, they highlighted the increased vulnerability of Mexican G. hirsutum landrace accessions to possible extinction. The new urgency for collection is occurring at a time when funding constraints, international treaties, national material transfer agreements, and other political and legal impediments have increased the complexity and difficulty of collecting. One partial solution to these problems may be collaborative multinational collecting efforts that include host countries. These collecting efforts could be modeled on past CIRADUSDA-ARS cooperative efforts (Schwendiman et al., 1986).

Another method of germplasm acquisition that has been widely used has been collection-to-collection germplasm exchanges. As with collecting in native habitat, this acquisition technique has become more complex. Germplasm exchange among different countries has become a more sensitive issue as the potential economic impact of germplasm has become more widely recognized. Although past exchange efforts have been successful in broadening the variability of participating germplasm collections, more strategic efforts may be needed in the future to fill specific gaps in collections and create duplicative backups of critical germplasm. International germplasm exchanges provide additional germplasm security when germplasm accessions are maintained at multiple sites across the world.

Challenges faced in germplasm conservation and regeneration are primarily economic in nature. The specialized facilities required for long-term preservation of germplasm face increasing energy and maintenance costs. In developing countries, the costs of developing infrastructure for germplasm preservation also are increasing. Regeneration of germplasm in collections creates challenges due to the photoperiodic nature of much of the genus. The tropical nurseries required for seed regeneration create attendant costs related to maintaining these nurseries and travel, as well as creating the regulatory complexity of international transport. Long-term financial support will be necessary to preserve germplasm resources while addressing rising energy costs, infrastructure development costs, and costs associated with tropical nurseries. Limiting or controlling the number of accessions in collections is being considered as a strategy for husbanding financial resources. However, this strategy may seriously conflict with the objective of conserving the genetic variability of the collections. One solution may be for the global community to create and maintain a common core collection of germplasm accessions that captures most of the Gossypium genetic variability, in addition to collection of specific genetic outliers, in duplicate at different collection centers. A serious drawback to this idea is the current inadequate characterization of the genetic variation present within the genus. There may be more immediate opportunities for resource sharing, such as shared tropical nurseries for regeneration.

One strategy for germplasm conservation, perhaps of limited applicability, is in situ preservation. Few examples of the implementation of active in situ preservation efforts currently exist for cotton. One successful example is an effort to protect native colonies of the species G. mustelinum in Brazil (Barroso et al., 2006, 2009). Another example of an effort in progress is that of the Mexican government to preserve native Mexican Gossypium accessions in a working garden nursery (Ulloa et al., 2006). A major drawback to this approach is that in many instances wild species exist in areas that are being actively developed for commercial production of cotton. In these situations, wild species historically have been viewed as hosts for insect and disease pests, and in some instances, they have been actively eradicated.

Characterization and evaluation of germplasm collections is perhaps the greatest challenge facing collections. Tables 1 and 2 clearly demonstrate the vast germplasm resources present across the eight major cotton germplasm collections of this report. However, simply summing the total number of accessions across the eight collections does 
not provide a representation of the diversity across these collections. All major collections have instituted characterization of their holdings utilizing phenotypic descriptors. However, in many instances descriptors are botanical or taxonomic in nature and do not include agronomic traits of interest to breeders and improvement efforts. Collecting agronomic trait data through germplasm evaluation often requires replicated testing across years and environments and is beyond the resources of individual collection curators. Thus, an opportunity exists among and between collections, with the assistance of cotton breeders and geneticists of their respective countries, to implement planned coordinated evaluation efforts.

In addition to agronomic germplasm evaluations, emerging DNA marker technologies provide powerful characterization tools for collections. Current characterization efforts utilizing molecular markers, while informative, have been fragmentary and unsystematic and therefore their results cannot be readily combined to provide a comprehensive view of the diversity represented in collections. Using a common set of core DNA markers, as proposed by ICGI, would allow for accurate measures of genetic diversity within and among global cotton germplasm collections and assist in the selection of a core set of germplasm accessions representing most of the genetic variability. A common framework marker set would also provide an anchor source of reference for accessions and gene mining at different germplasm centers. Application of a common set of framework markers also offers the ability to detect redundancy within and among collections at the global level. The use of molecular markers could also contribute to the creation of core germplasm collections. The concept of developing core germplasm collections was introduced by Brown (1989) and has been implemented in a number of other important crop plants including peanut (Arachis hypogaea L.) (Holbrook et al., 1993) and rice (Oryza sativa L.) (Yan et al., 2007). Core collection strategies should decrease costs associated with germplasm conservation over time. In addition to decreased germplasm conservation costs over time, the development of a global core germplasm collection could also provide a tool to standardize agronomic and end-use performance data. The core collection or a smaller subset of the core collection could be included in all germplasm accession evaluation trials conducted across collections and countries to provide a globally useful data set. The combination of molecular and agronomic data collected on core germplasm collection(s) will provide cotton geneticists and breeders vast opportunities to mine the cotton genome for important genetic loci using powerful genomics technologies of 21st century (Gupta et al., 2005; Abdurakhmonov and Abdukarimov, 2008; Zeng et al., 2009).

Finally, current and future germplasm characterization data should be stored using databases that are both easily available and synergistically connected. Database uniformity, accessibility, and connectivity are critical to efficiently use the germplasm resources available across the world. Several impediments to creation of such an integrated system presently exist and include unrecognized redundancy in collections due to nonuniform nomenclature for accessions, nonuniform data collection across collections, and lack of uniformity or synonymy in descriptors, to name a few. Addressing these concerns is compulsory to ensure the longterm security and availability of the global cotton germplasm resources. It is important to develop an international network to promote the dissemination of germplasm resource data. An improved germplasm database or linkage of existing databases that incorporates morphological, field performance, and molecular data will help to associate specific markers and alleles with traits of interest. Generating new molecular data within and among our global germplasm collections also offers the opportunity to develop uniform data collection standards and guidelines that include descriptor, agronomic, and molecular data types.

Currently the USDA-ARS is engaged in a project, GRIN-Global, to create a global plant genetic resource information management system. This collaborative effort with the Global Crop Diversity Trust and Bioversity International has as its goal the creation of a sustainable, rational, efficient, and effective global network of gene banks to permanently safeguard plant genetic resources and encourage the use of genetic resources by researchers, breeders, and farmer-producers. Participating germplasm resource collections of the ICGI are following the efforts of GRIN-Global with great interest and hope to benefit from this collaborative effort.

In summary, this report provides a brief description of the major cotton germplasm collections present in the world today. Simply summing the total number of accessions held across the collections provides evidence for the wealth of germplasm resources available to cotton scientists around the globe. However, this document also identifies the numerous challenges and opportunities facing future acquisition, conservation, characterization, and documentation efforts of the global cotton germplasm collections. Among concerns communicated by germplasm collection centers are (i) long-term financial support for germplasm conservation and storage infrastructure improvements, (ii) future germplasm exploration and international exchange, (iii) data collection guidelines and uniformity, and (iv) database storage and accessibility.

This report emphasizes the importance of international collaboration to protect, secure, and evaluate the global cotton germplasm resources. Without global, collaborative efforts to collect, protect, and secure cotton germplasm, the rarest and most unique cotton germplasm resources are vulnerable to extinction. Multinational collaboration is essential because the international research and germplasm conservation centers that are part of the 
CGIAR do not actively maintain and preserve cotton germplasm resources. Hence, coordination and collaboration among the cotton germplasm collections mentioned in this report are vital to the global cotton community. Recently, a collaborative research project between U.S. and Uzbek scientists provided an opportunity to exchange $>900$ cotton germplasm accessions and to develop a germplasm passport database system in Uzbekistan that is based on molecular and phenotypic data, including agronomic and end-use traits (Abdurakhmonov et al., 2008a, 2008b).

Overall, this report serves as a unique starting point for the global cotton community to build strong, multinational collaborations. The collaborative effort of scientists representing the countries and institutions mentioned in this report is a powerful example of benefiting the global cotton community by effectively applying the core principles outlined by the ICGI: to facilitate (i) global communication, collaboration, and education; (ii) knowledge and resource integration; (iii) technology and resource development; and (iv) coordinated research planning.

\section{References}

Abdalla, A.M., O.U.K. Reddy, K.M. El-Zik, and A.E. Pepper. 2001. Genetic diversity and relationships of diploid and tetraploid cottons revealed using AFLP. Theor. Appl. Genet. 102:222-229.

Abdullaev, A.A., V.P. Klyat, and C.M. Rizaeva. 2009. Cotton introduction in Uzbekistan-History and perspectives of using of plant introduction: Problems and perspectives. (In Russian.) p. 59-61. In Proc. of Natl. Scientific-Applied Conf., 4th, Tashkent, Uzbekistan. 3-4 July 2009.

Abdukarimov, A., S. Djataev, and I.Y. Abdurakhmonov. 2003. Cotton research in Uzbekistan: Elite varieties and future of cotton breeding. p. 5-15. In Proc. of World Cotton Res. Conf., 3rd, Cape Town, South Africa. 9-136 March 2003.

Abdurakhmonov, I.Y. 2007. Exploiting genetic diversity. p. 2153. In D. Ethridge (ed.) Plenary presentations and papers. Proc. of World Cotton Res. Conf., 4th, Lubbock, TX. 10-14 Sept. 2007.

Abdurakhmonov, I.Y., and A. Abdukarimov. 2008. Application of association mapping to understanding the genetic diversity of plant germplasm resources. Int. J. Plant Genom. 2008:Article 574927.

Abdurakhmonov, I.Y., A.A. Abdullaev, S. Saha, Z.T. Buriev, D. Arslanov, Z. Kuryazov, G.T. Mavlonov, S.M. Rizaeva, U.K. Reddy, J.N. Jenkins, A. Abdullaev, and A. Abdukarimov. 2005. Simple sequence repeat marker associated with a natural leaf defoliation trait in tetraploid cotton. J. Hered. 96:644-653.

Abdurakhmonov, I.Y., Z.T. Buriev, I.B. Salakhuddinov, S.M. Rizaeva, A.T. Adylova, S.E. Shermatov, A. Adukarimov, R.J. Kohel, J.Z. Yu, A.E. Pepper, S. Saha, and J.N. Jenkins. 2006. Characterization of $G$. hirsutum wild and variety accessions from Uzbek cotton germplasm collection for morphological and fiber quality traits and database development. p. 5306. In Proc. Cotton Beltwide Conf., San Antonio, TX. 3-6 Jan. 2006.

Abdurakhmonov, I.Y., R.J. Kohel, J.Z. Yu, A.E. Pepper, A.A. Abdullaev, F.N. Kushanov, I.B. Salakhutdinov, Z.T. Buriev, S. Saha, B.E. Scheffler, J.N. Jenkins, and A. Abdukarimov. 2008a. Molecular diversity and association mapping of fiber quality traits in exotic G. hirsutum L. germplasm. Genomics 92:478-487.
Abdurakhmonov, I.Y., F.N. Kushanov, F. Djaniqulov, Z.T. Buriev, A.E. Pepper, N. Fayzieva, G.T. Mavlonov, S. Saha, J.N. Jenkins, and A. Abdukarimov. 2007. The role of induced mutation in conversion of photoperiod dependence in cotton. J. Hered. 98:258-266.

Abdurakhmonov, I.Y., S. Saha, J.N. Jenkins, Z.T. Buriev, S.E. Shermatov, B.E. Scheffler, A.E. Pepper, J.Z. Yu, R.J. Kohel, and A. Abdukarimov. 2008b. Linkage disequilibrium based association mapping of fiber quality traits in G. hirsutum L. variety germplasm. Genetica (The Hague) 136:401-417.

Almeida, V.C., L.V. Hoffmann, G.K. Yokomizo, J.N. Costa, M. Giband, and P.A.V. Barroso. 2009. In situ characterization of Gossypium barbadense populations from the states of Pará and Amapá, Brazil. Pesq. Agrop. Brasil. 44:719-725.

Barroso, P.A.V., E.C. Freire, J.A.B. do Amaral, and L.V. Hoffmann. 2006. Zona de exclusão de transgênicos preserva populações in situ. Visão Agríc. 6:23-25.

Barroso, P.A.V., L.V. Hoffmann, R.B. Freitas, C.E.A. Batista, M.F. Alves, U.C. Silva, and F.P. Andrade. 2009. In situ conservation and genetic diversity of three populations of Gossypium mustelinum Miers ex Watt. Genet. Res. Crop Evol. 57:343-349.

Beasley, J.O. 1942. Meiotic chromosome behavior in species, species hybrids, haploids and induced polyploidy of Gossypium. Genetics 27:25-54.

Brown, A.H.D. 1989. Core collections: A practical approach to genetic resources management. Genome 31:818-824.

Brubaker, C., R. Cantrell, M. Giband, B. Lyon, and T. Wilkins. 2000. Letter to Journal of Cotton Science community from the steering committee of the International Cotton Genome Initiative (ICGI). J. Cotton Sci. 4:149-151.

Brubaker, C.L., F.M. Bourland, and J.F. Wendel. 1999. The origin and domestication of cotton. p. 3-31. In C.W. Smith and J.T. Cothren (ed.) Cotton: Origin, history, technology, and production. John Wiley \& Sons, New York.

Campbell, B.T., V.E. Williams, and W. Park. 2009. Using molecular markers and field performance data to characterize the Pee Dee cotton germplasm resources. Euphytica 169:285-301.

Chaudhary, B., L. Flagel, R.M. Stupar, J.A. Udall, N. Verma, N.M. Springer, and J.F. Wendel. 2009. Reciprocal silencing, transcriptional bias and functional divergence of homeologs in polyploid cotton (Gossypium). Genetics 182:503-517.

Constable, G.A., N.J. Thomson, and P.E. Reid. 2001. Approaches utilized in breeding and development of cotton cultivars in Australia. p. 1-15. In J.N. Jenkins and S. Saha (ed.) Genetic improvement of cotton: Emerging technologies. Sci. Publ., Enfield, NH.

Craven, L.A., J. McD. Stewart, A.H.D. Brown, and J.P. Grace. 1994. The Australian wild species of Gossypium. p. 278-281. In G.A. Constable and N.W. Forrester (ed.). Proc. of the World Cotton Res. Conf., 1st, Brisbane, Australia. 13-17 Feb. 1994.

Damania, A.B. 2008. History, achievements, and current status of genetic resources conservation. Agron. J. 100:9-21.

Dejoode, D.R., and J.F. Wendel. 1992. Genetic diversity and origin of the Hawaiian Islands cotton, Gossypium tomentosum. Am. J. Bot. 79:1311-1319.

Dessauw, D., and B. Hau. 2006. Inventory and history of the CIRAD cotton (Gossypium spp.) germplasm collection. Plant Genet. Resour. Newsl. 148:1-7.

Dilday, R.H., and T.N. Shaver. 1976. Survey of the regional Gossypium hirsutum L. primitive race collection for flowerbud gossypol. USDA-ARS Publ. ARS-S-80, January 1976. USDA, Beltsville, MD.

Dillehay, T.D., J. Rossen, T.C. Andres, and D.E. Williams. 2007. 
Preceramic adoption of peanut, squash, and cotton in Northern Peru. Science 316:1890-1893.

Djaniqulov, F. 2002. About relation between radio-sensitivity and mutability of wild and tropical cultivated cotton forms. Proc. Russ. Acad. Agric. Sci. 2:19-22.

FAO. 2009. International treaty on plant genetic resources for food and agriculture. Available at ftp://ftp.fao.org/docrep/fao/011/ i0510e/i0510e.pdf (verified 19 Mar. 2010). FAO, Rome.

Fryxell, P.A. 1976. Germpool utilization: Gossypium, a case history. USDA-ARS Publ. ARS-S-137, August 1976. USDA, Washington, DC.

Fryxell, P.A. 1992. A revised taxonomic interpretation of Gossypium L. (Malvaceae). Rheedea 2:108-165.

Gingle, A.R., H. Yang, P.W. Chee, O.L. May, J. Rong, D.T. Bowman, E.L. Lubbers, J.L. Day, and A.H. Paterson. 2006. An integrated web resource for cotton. Crop Sci. 46:1998-2007.

Gupta, P.K., S. Rustgi, and P.L. Kulwal. 2005. Linkage disequilibrium and association studies in higher plants: Present status and future prospects. Plant Mol. Biol. 57:461-485.

Gutierrez, O.A., S. Basu, S. Saha, J.N. Jenkins, D.B. Shoemaker, C.L. Cheatham, and J.C. McCarty, Jr. 2002. Genetic distance among selected cotton genotypes and its relationship with $\mathrm{F}_{2}$ performance. Crop Sci. 42:1841-1847.

Harlan, J.R., and J.M.J. de Wet. 1971. Towards a rational classification of cultivated plants. Taxon 20:509-517.

Hawkins, J.S., J. Pleasants, and J.F. Wendel. 2005. Identification of AFLP markers that discriminate between cultivated cotton and the Hawaiian island endemic, Gossypium tomentosum Nuttall ex Seeman. Genet. Resour. Crop Evol. 52:1069-1078.

Holbrook, C.C., W.F. Anderson, and R.N. Pittman. 1993. Selection of a core collection from the U.S. germplasm collection of peanut. Crop Sci. 33:859-861.

Hopkins, D.L., and A.H. Purcell. 2002. Xyella fastidiosa: Cause of Pierce's disease of grapevine and other emergent diseases. Plant Dis. 86:1056-1066.

Hutchinson, J.B., R.A. Silow, and S.G. Stephens. 1947. The evolution of Gossypium and the differentiation of the cultivated cottons. Oxford Univ. Press, London.

IBPGR Secretariat. 1985. International Board for Plant Genetic Resources cotton descriptors (revised). October 1979. IPBGR Working Group, Rome.

Ibragimov, P.S., V.A. Avtonomov, A.B. Amanturdiev, S.E. Namazov, D.E. Zaurov, T.J. Molnar, S.W. Eisenman, T.J. Orton, C.R. Funk, J. Percival, and A. Edward. 2008. Uzbek Scientific Research Institute of Cotton Breeding and Seed Production: Breeding and germplasm resources. J. Cotton Sci. 12:62-72.

Kohel, R.J. 1978. Survey of Gossypium hirsutum L. germplasm collections for seed-oil percentage and seed characteristics. USDA-ARS Publ. ARS-S-187, November 1978. USDA, Washington, DC.

May, O.L., D.T. Bowman, and D.S. Calhoun. 1995. Genetic diversity of U.S. upland cotton cultivar releases between 1980 and 1990. Crop Sci. 35:1570-1574.

McCarty, J.C., and R.G. Percy. 2001. Genes from exotic germplasm and their use in cultivar improvement in Gossypium hirsutum L. and G. barbadense L. p. 65-80. In J.N. Jenkins and S. Saha (ed.) Genetic improvement of cotton-Emerging technologies. Sci. Publ., Enfield, NH.

Musaev, J.A., M.F. Abzalov, A. Almatov, M.F. Sanamyan, N. Gubanova, and U. Nadjimov. 2000. Cotton genetics and genetic collection of isogenic, monosomic and translocation lines. p.
28-39. In Bull. SCST Repub. Uzb. Tashkent, Uzbekistan.

Neves, O.S., P.A. Cavaleri, I.R. Grid-Papp, and M.G. Fuzzato. 1965. Algodoeiro selvagem do Nordeste do Brasil. Bragantia 24:19-25.

Neves, O.S., I.R. Grid-Papp, P.A. Cavaleri, C.A.M. Ferraz, M.G. Fuzzato, N.M. Silva, W. Schmidt, and D.M. Correa. 1968. Distribuição geográfica atual dos algodoeiros perenes no Brasil, primeiro levantamento parcial. Bragantia 27:437-475.

Paterson, A.H., R.K. Boman, S.M. Brown, P.W. Chee, J.R. Gannaway, A.R. Gingle, O.L. May, and C.W. Smith. 2004. Reducing the genetic vulnerability of cotton. Crop Sci. 44:1900-1901.

Percival, A.E. 1987. The national collection of Gossypium germplasm. South. Coop. Ser. Bull. 321, June 1987. USDA, Washington, DC.

Percival, A.E., and R.J. Kohel. 1990. Distribution, collection and evaluation of Gossypium. Adv. Agron. 44:225-256.

Percival, A.E., J.F. Wendel, and J.M. Stewart. 1999. Taxonomy and germplasm resources. p. 33-64. In C.W. Smith and J.T. Cothren (ed.) Cotton: Origin, history, technology, and production. John Wiley \& Sons, New York.

Percy, R.G. 2008. Cotton germplasm collections: Opportunities and challenges. In Int. Cotton Genome Initiative (ICGI) 2008 Int. Conf., Anyang, China. 8-11 July 2008.

Percy, R.G., and J.F. Wendel. 1990. Allozyme evidence for the origin and diversification of Gossypium barbadense L. Theor. Appl. Genet. 79:529-542.

Pickersgill, B., S.C.H. Barrett, and D.A. Lima. 1975. Wild cotton in Northeast Brazil. Biotropica 7:42-54.

Ploetz, R.C., and K.G. Pegg. 1997. Fusarium wilt of banana and Wallace's line: Was the disease originally restricted to his Indo-Malayan region? Australas. Plant Pathol. 26:239-249.

Ramanatha Rao, V., and T. Hodgkin. 2002. Genetic diversity and conservation and utilization of plant genetic resources. Plant Cell Tissue Organ Cult. 68:1-19.

Rizaeva, S.M. 1996. Interspecific hybridization of cotton and development of new cotton donor accessions (in the example of New World cottons). Ph.D. diss. Inst. of Plant Exp. Biol. of the Acad. of Sci. of Uzbekistan, Tashkent, Uzbekistan.

Rizaeva, S.M., A.A. Abdullaev, V.P. Klyat, D.M. Arslonov, and Z.B. Kuryazov. 2001. Creation of donors with naturally early leaf defoliation. Uzbek Biol. J. 4:65-70.

Robinson, A.F., A.A. Bell, N.D. Dighe, M.A. Menz, R.L. Nichols, and D.M. Stelly. 2007. Introgression of resistance to nematode Rotylenchulus reniformis into Upland cotton (Gossypium hirsutum) from Gossypium longicalyx. Crop Sci. 47:1865-1877.

Rubenstein, K.D., P. Heisey, R. Shoemaker, J. Sullivan, and G. Frisvold. 2005. Crop genetic resources: An economic appraisal. In Econ. Info. Bull. 2, May 2005. USDA, ERS, Washington, DC.

Sanamyan, M.F., and E.M. Rakhmatullina. 2003. Cytogenetic analysis of translocations in cotton. Plant Breed. 122:511-516.

Schwendiman, J., A.E. Percival, and J.L. Bélot. 1986. Cotton collection on Caribbean islands and south Florida. Plant Genet. Resour. Newsl. 66:2-5.

Singh, V.V., M. Punit, V.N. Kulkarni, S.J. Baitule, and B.R. Pathak. 2003. Exploration within India for collection of cotton species germplasm. Plant Genet. Resour. Newsl. 136:40-46.

Smith, C.W., R.G. Cantrell, H.S. Moser, and S.R. Oakley. 1999. History of cultivar development in the United States. p. 99-172. In C.W. Smith and J.T. Cothren (ed.) Cotton: Origin, history, technology, and production. John Wiley \& Sons, 
New York.

Stewart, J.M. 1994. Potential for crop improvement with exotic germplasm and genetic engineering. p. 313-327. In Proc. of World Cotton Res. Conf., 1st, Brisbane, Australia. 13-17 Feb. 1994.

Tatum, L.A. 1971. The Southern corn leaf blight epidemic. Science 171:1113-1116.

Todaro, A. 1877. Relazione sulla cultura dei cotoni in Italia seguita da una monografia del genere Gossypium. Molina, Rome.

Ulloa, M., J.M. Stewart, E.A. Garcia-C., S. Godoy-A., A. Gaytan-M., and S. Acosta N. 2006. Cotton genetic resource in the western states of Mexico: In situ conservation status and germplasm collection for ex situ preservation. Genet. Resour. Crop Evol. 53:653-668.

USDA. 1956. The genetics and cytology of cotton, 1948-55. South. Coop. Ser. Bull. 47. USDA, Washington, DC.

USDA-ARS. 1977. Systematic collections of the Agricultural Research Service. USDA-ARS Misc. Publ. 1343. USDA, Washington, DC.

Van Becelaere, G., E.L. Lubbers, A.H. Paterson, and P.W. Chee. 2005. Pedigree- vs. DNA marker-based genetic similarity estimates in cotton. Crop Sci. 45:2281-2287.

Van Esbroeck, G., and D.T. Bowman. 1998. Cotton germplasm diversity and its importance to cultivar development. J. Cotton Sci. 2:121-129.

Van Esbroeck, G., D.T. Bowman, D.S. Calhoun, and O.L. May. 1998. Changes in the genetic diversity of cotton in the USA from 1970 to 1995. Crop Sci. 38:33-37.

von Rohr, J.B.P. 1791-1793. Anmerkungen über den Cattunbau, zum Nuzen der Danischen Westindischen Colonien. Hamrich, Altona and Leipzig.

Wallace, T.P., D.T. Bowman, B.T. Campbell, P. Chee, O.A.
Gutierrez, R.J. Kohel, J. McCarty, G. Myers, R. Percy, F. Robinson, W. Smith, D.M. Stelly, J.M. Stewart, P. Thaxton, M. Ulloa, and D.B. Weaver. 2009. Status of the USA cotton germplasm collection and crop vulnerability. Genet. Resour. Crop Evol. 56:507-532.

Wendel, J.F., and R.C. Cronn. 2002. Polyploidy and the evolutionary history of cotton. Adv. Agron. 78:139-186.

Wendel, J.F., and R.G. Percy. 1990. Allozyme diversity and introgression in the Galapagos Islands endemic Gossypium darwinii and its relationship to continental G. barbadense. Biochem. Syst. Ecol. 18:517-528.

Wendel, J.F., R. Rowley, and J. Stewart. 1994. Genetic diversity in and phylogenetic relationships of the Brazilian endemic cotton, Gossypium mustelinum (Malavaceae). Plant Syst. Evol. 192:49-59.

Wendel, J.F., A. Schnabel, and T. Seelanan. 1995. An unusual ribosomal DNA sequence from Gossypium gossypioides reveals ancient, cryptic, intergenomic introgression. Mol. Phyl. Evol. 4:298-313.

Westengen, O.T., Z. Huamán, and M. Heun. 2005. Genetic diversity and geographic pattern in early South American cotton domestication. Theor. Appl. Genet. 110:392-402.

Yan, W., J.N. Rutger, R.J. Bryant, H.E. Bockelman, R.G. Fjellstrom, M.-H. Chen, T.H. Tai, and A.M. McClung. 2007. Development and evaluation of a core subset of the USDA rice germplasm collection. Crop Sci. 47:869-878.

Zeng, L., W.R. Meredith, Jr., O.A. Gutiérrez, and D.L. Boykin. 2009. Identification of associations between SSR markers and fiber traits in an exotic germplasm derived from multiple crosses among Gossypium tetraploid species. Theor. Appl. Genet. 119:93-103. 